\title{
Realization of the Concept of the Belt and Road Initiative Based on the Development of Digitalization Processes in the Field of International Trade
}

\author{
Olga Nikulina \\ Department of World Economy and Management \\ Kuban State University \\ Krasnodar, Russia \\ Olgafinans@mail.ru
}

\begin{abstract}
The article is dedicated to the study of digitalization processes in the field of international trade from the point of view of implementation of the concept of the Belt and Road Initiative. The role and importance of digital technologies in the development of international trade, deepening foreign trade specialization and strengthening the integration of all participants in foreign economic activity involved in the implementation of the Belt and Road project have been revealed. The interconnection and mutual influence of digitalization processes in international trade on the development of related industries have been substantiated. Measures aimed to develop digitalization processes in international trade, considering the need to ensure economic security and control the operations of international trade participants as part of the implementation of the Belt and Road concept, have been proposed.
\end{abstract}

Keywords: digitalization, international trade, e-commerce, innovation, digital technologies

\section{INTRODUCTION}

International trade is now subject to a major transformation of all processes and operations under the influence of political and economic relations between participating countries, as well as the introduction of digital technologies in all business processes and models [1]. Accelerating international settlements and building new forms of foreign trade communications using the digitization of international trade operations allows to predict the establishment of new ways of organizing exchange processes and making sales transactions. The influence of digitalization on the development of international trade is twofold, causing, on the one hand, the transformation of communication and relationships of trade participants, and on the other hand, contributing to the formation of consumer demand for new products and services created using artificial intelligence and based on the application of innovative technologies [2]. In this regard, it is particularly important to identify the role and importance of digital technologies in the development of international trade, deepening foreign trade specialization and strengthening the integration of all participants in foreign economic activities implementing the Belt and Road project.

\section{METHODS OF RESEARCH INTO THE DigITALIZATION OF INTERNATIONAL TRADE OF THE BELT AND ROAD PROJECT PARTICIPANTS}

The concept of the Belt and Road Initiative is aimed at the development of global economic cooperation between the countries of Eurasia and provides for the creation of a largescale infrastructure that ensures the development of international trade [3]. The project was initiated by China, combines over 70 countries with population of over 3 billion people, GDP of 21 trillion dollars, and provides for investment of more than 1 trillion dollars. Implementation of the Belt and Road concept concerns interests of various countries and assumes development of strategic partnership within the framework of international cooperation. Figure 1 demonstrates the characteristic of main elements of implementation of the Belt and Road Initiative. Currently over 124 countries and 29 international organizations have signed the cooperation agreement with China as part of this project, which includes two main branches: the Silk Road Economic Belt and the 21stcentury Maritime Silk Road. The Silk Road Economic Belt is also sometimes referred to as the "Economic Belt." The project envisages the creation of land infrastructure corridors that will connect China with the countries of Asia, the Middle East and Europe. The second direction of the 21st-century Maritime Silk Road project involves the formation of two main routes through the South China Sea to the South Pacific and the Indian Ocean, as well as the construction of an additional route along the Northern Sea Route through the inland waters of Russia ("Ice Silk Road"). This additional route through the Arctic will allow to expand cooperation and provide a new direction for the project auxiliary to the existing international trade one: joint implementation of energy projects and for the development of research activities. 


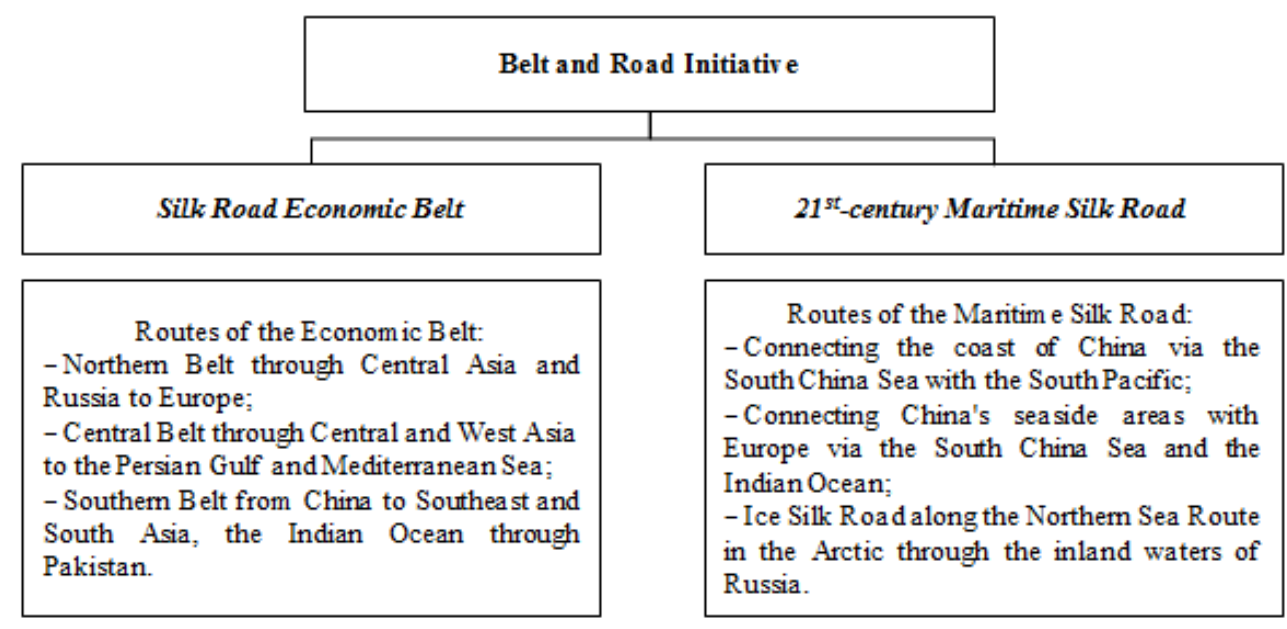

The m ain socio-econom ic indicators of the project are:
- Cooperation a greem ent was signed by 124 countries and 29 international organizations;
- Planned investm ent for the project is m ore than $\$ 1$ trillion;
- Project covers more than 3 billion people, representing $63 \%$ of the world's population, with a total
GDP of about $\$ 21$ trillion;
- Trade with the Belt and Road countries will ex ceed $\$ 2.5$ trillion per year;
- Chinese com panies have built 56 zones of trade and econom ic cooperation and invested about 50
billion dollars, created 180,000 jobsfor residents of the countries participating in the project;
- In eight ASE AN countries, China has established 300 enterprises with a total investm ent of $\$ 1.77$
billion;
- In 2018 , the volum e of imports and ex ports of goods between the participating countries and China
reached 1.3 trillion dollars;
- The China Developm ent Bank (CDB) has financed m ore than 600 infrastructure projects worth $\$ 190$
billion;
- China created the Silk Road Fund with an initial capital of $\$ 10$ billion and a subsequent increase to
$\$ 40$ billion, the One Belt, One Road investm ent fund with a capital of $\$ 3.2$ billion, with a gain of $\$ 16$
billion, and the Asian Infra structure Investm ent Bank with a share capital of $\$ 100$ billion.

Competing integration initiatives, with which it was possible to im plem ent the agreem ent in the political sphere, are:

Eurasian Economic Union (EAEU), Indian "Go-West" program, Japanese "Quality Infra structure" program, Kazakhstan "Nurly Zhol" infrastructure program, Turkish "Middle Corrido" program, Mongolian "Developm ent Path" program, Vietnam ese "Two corridors, one econom ic belt" project, the UK's Northem Powerhouse strategy, and Polish "Am ber Roa d" project.

Fig. 1. Characteristics of the main elements of the implementation of the concept of the Belt and Road Initiative

However, it should be noted that the main goal of the Belt and Road concept is to develop a network of new land and sea routes linking export centers with remote markets. The infrastructure created within the project will simplify supply chains, reduce business costs, and intensify international trade.

The new impetus for the development of international trade for all participants in the Belt and Road project today can come from digital technologies that are actively developed and implemented in all areas of economic activity. International trade is embedded in the architectures of the world economy and is influenced by modern digitalization processes, which are based on innovations that ensure the transition to a new format of economic relations. Digitalization of the world economy, in turn, it is related to the formation as key factors of production of new data presented in digital form, which allow to significantly improve the efficiency and quality of business processes and productivity in various types of activities of economic entities [4]. Let us highlight the main elements of the digital economy, which have a significant impact on the development in the area of international trade:

- e-commerce, which accelerates exchange and communication processes in international trade;

- e-banking as a digital technology in the banking field of international trade participants, which reduces the time spent on interactions between customers and banks;

- electronic payments that speed up settlement operations in international trade and ensure information 


\section{Infrastructural aspects}

Ensuring the creation of transport, logistics, financial infrastructure through the introduction of digital technologies in international trade on all routes and stages of the Belt and Road project that will create the basis for the development of all participating countries.

\section{Economic aspects}

Penetration of digital technologies into international trade significantly reduces the transaction costs of the Belt and Road project participants and creates the conditions for the development of fundamentally new forms and models of doing business. The development of e-commerce allows to save on expensive trading platforms, optimize and reduce logistics costs, use global online platforms to accelerate trading operations.

\section{Multiplicative aspects}

Creation of the multiplicative effect of the development of related industries and economic activities through the introduction of digital technologies in international trade, as well as formation of new conditions for deepening foreign trade specialization and strengthening the integration interaction of the Belt and Road project participants.

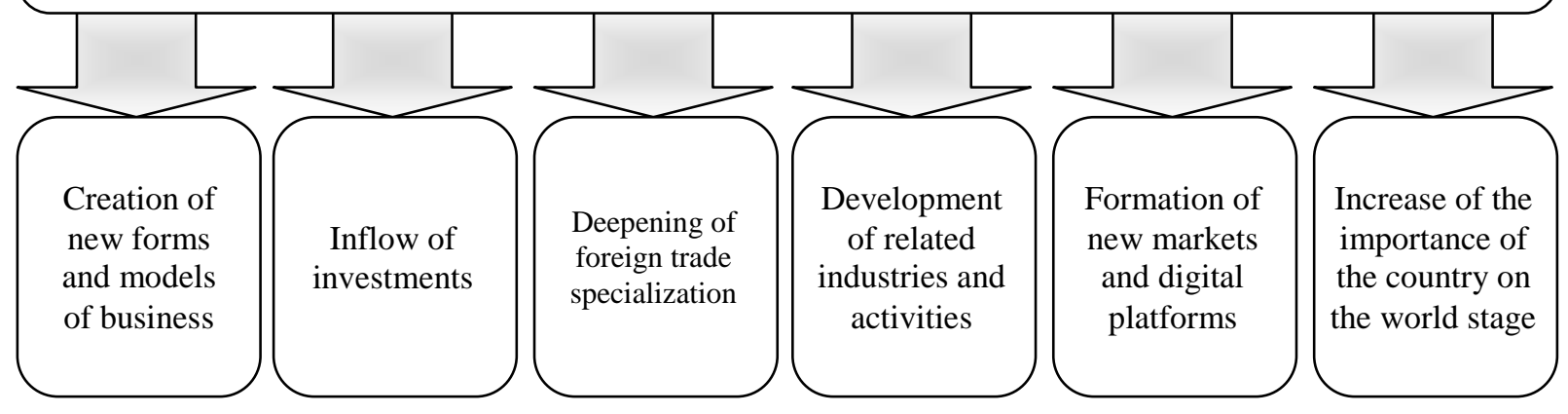

Fig. 2. Characteristics of the main elements of the implementation of the concept of the Belt and Road Initiative

and financial flows exchange between authorized correspondent banks;

- electronic payment systems and cryptocurrencies, allowing participants in international trade to make electronic payments on settlement transactions using the Internet system;

- digital marketing, which includes online advertising as its core element and uses social media, social networks and online games as a primary tool to organize and hold promotions for buyers in the form of in-game models;

- digital intermediaries of online platforms, which enable real-time sales and create the prerequisites for the formation of new business models in international trade;
- Internet of Things and the Internet of Values, allowing for the introduction of an effective system of control in the field of transport and warehouse maintenance of foreign trade operations;

- Artificial Intelligence technologies that develop software algorithms in international trade;

- automation and robotization of handling in international trade.

The digital transformation of international trade is based on the development and improvement of information technology, with the simultaneous proliferation of mobile networks and Internet [5]. The digitalization of the world economy creates an opportunity for the development of international trade at a qualitatively new level, and in its turn, international trade ensures the spread of digital technologies in 
the world. We need to note the twofold nature of influence of digitalization on the development of the world economy. On the one hand, digitalization accelerates and simplifies major business processes in international trade and saves all kinds of costs, while, on the other hand, it transforms traditional forms and models and fundamentally alters the communication system between international trade participants.

The digital transformation of international trade encompasses all business processes and significantly alters the entire system of economic relations of the participants of the Belt and Road project. Due to the complexity and uncertainty of innovative processes in the field of infrastructure construction on all routes of the Belt and Road, there is a need to create new forms of interaction of all participants in foreign economic activity within the framework of the implementation of the concept of the Belt and Road Initiative. One of key results of this process is the formation of completely new business models that ensure active introduction of digital technologies in international trade.

The formation of a digital economy based on the development of integration processes in international trade in the face of increased competition leads to the transformation of the economic interests of the countries participating in the Belt and Road project, which requires the development of new approaches to the disclosure of the essence and content of the mechanism of interaction of economic actors within the framework of the implementation of the concept of the Belt and Road Initiative based on the synthesis of institutional theory and systemic approach, which makes up the methodology of this research. Institutional theory provides justification for the development of international trade in the context of the digitalization of the world economy and identifies the main elements that enable the countries participating in the Belt and Road project to implement key competencies through the introduction of digital technologies into business processes.

Figure 2 reflects three aspects of the role and importance of digital technologies in the development of international trade, deepening foreign trade specialization and strengthening the integration of all participants in the Belt and Road project, taking into account the analysis of institutional theory and the application of a systemic approach.

The complexity and ambiguity of the problem of digitizing the economy in international trade has led to a number of concepts, each of which focuses on the study of a certain aspect of the problem, but does not allow for their systematic perception and overcoming [7]. To solve this problem, the most appropriate conceptual understanding of the analyzed phenomenon is the one based on a systemic approach, as the development of digitalization processes in the field of international trade is a special form of economic activity of economic entities, the various slices of which allow to identify and investigate the whole set of elements and relationships of the participants of the Belt and Road project.

\section{RESUlTS OF THE ANALYSIS OF THE DYNAMICS OF INTERNATIONAL TRADE CONSIDERING DIGITALIZATION OF THE WORLD ECONOMY}

The development of international trade during the postcrisis period of 2015-2018 happened rapidly, and during the last four years the leading countries have demonstrated increasing turnover in export and import operations [8]. The leading position among the exporting countries is occupied by China with export turnover during 2018 in the amount of $\$ 2$ 494 billion, which is $10.2 \%$ more than the export turnover of 2017 (\$ 2263 billion). The leader among importing countries is the United States with import turnover in 2018 in the amount of \$ 2611 billion, which is $16.1 \%$ more than the volume of imports in 2017 (\$ 2410 billion). Germany traditionally ranks third among exporting and importing countries, and shows stable growth dynamics in 2018 on export operations in the amount of $\$ 1563$ billion, which is $7.9 \%$ more compared to 2017. Similarly, the growth of German imports in 2018 amounted to \$ 1293 billion, which is $10.8 \%$ higher than in 2017 (\$1 167 billion) [9]. Russia in 2018 increased the volume of export operations to the level of \$ 451 billion, which is $25 \%$ more compared to 2017 , while import growth in 2018 amounted to $5.26 \%$ in the amount of \$ 240 billion. Figure 3 presents information on the dynamics of export operations of countries leading in international trade and Russia for the period of 2015-2018.

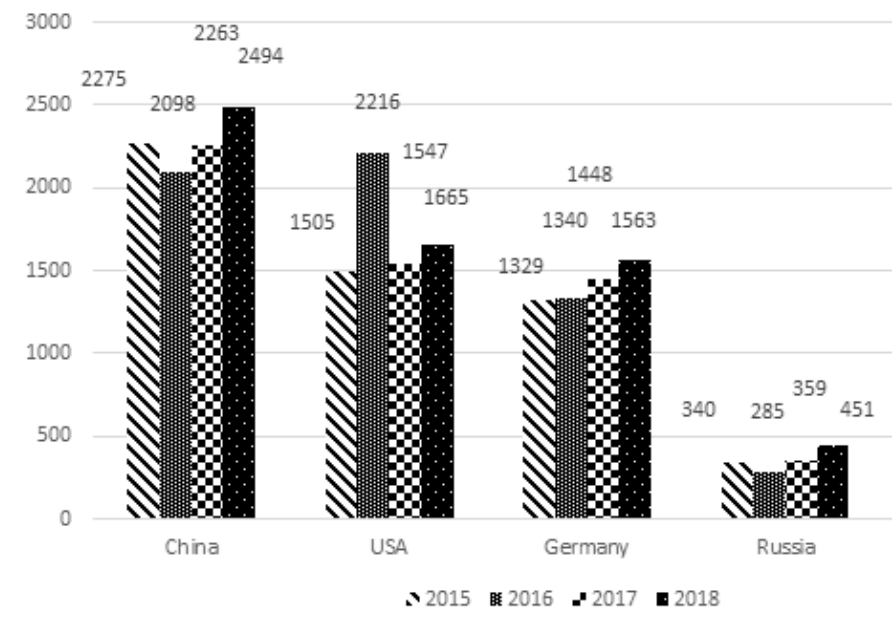

Fig. 3. The export dynamics of countries leading in international trade and Russia for the period of 2015-2018 [8,9]

Figure 4 shows the import dynamics of countries leading in international trade and Russia for the period of 2015-2018. 
TABLE I. PARTICIPATION OF LEADING COUNTRIES IN THE DEVELOPMENT OF ONLINE COMMERCE FOR THE PERIOD OF 2016-2018 [10, 11, 12, 13]

\begin{tabular}{|c|c|c|c|c|c|}
\hline Country & $\begin{array}{c}\text { 2016, } \\
\text { Billion \$ }\end{array}$ & $\begin{array}{l}\text { 2017, } \\
\text { Billion \$ }\end{array}$ & $\begin{array}{l}\text { 2018, } \\
\text { Billion \$ }\end{array}$ & $\begin{array}{c}\text { The share of online trade } \\
\text { in GDP, \% }\end{array}$ & $\begin{array}{c}\text { Share in global retail sales of } \\
\text { online commerce, } \%\end{array}$ \\
\hline China & 562.66 & 900.0 & 1330.0 & 4.5 & 47.6 \\
\hline United States & 349.06 & 423.0 & 513.0 & 2.6 & 18.4 \\
\hline United Kingdom & 93.89 & 102.7 & 199.1 & 7.9 & 7.2 \\
\hline Germany & 74.46 & 89.8 & 105.8 & 3.1 & 4.0 \\
\hline France & 42.62 & 43.1 & 44.5 & 1.8 & 1.6 \\
\hline Japan & 79.33 & 79.5 & 84.2 & 2.1 & 3.1 \\
\hline South Korea & 36.76 & 37.2 & 38.0 & 2.5 & 1.4 \\
\hline Canada & 28.77 & 29.8 & 33.6 & 2.3 & 1.2 \\
\hline Russia & 20.30 & 17.4 & 28.3 & 2.5 & 1.0 \\
\hline Brazil & 18.80 & 15.8 & 21.1 & 1.0 & 0.7 \\
\hline India & 10.10 & 11.7 & 22.9 & 1.0 & 0.8 \\
\hline
\end{tabular}

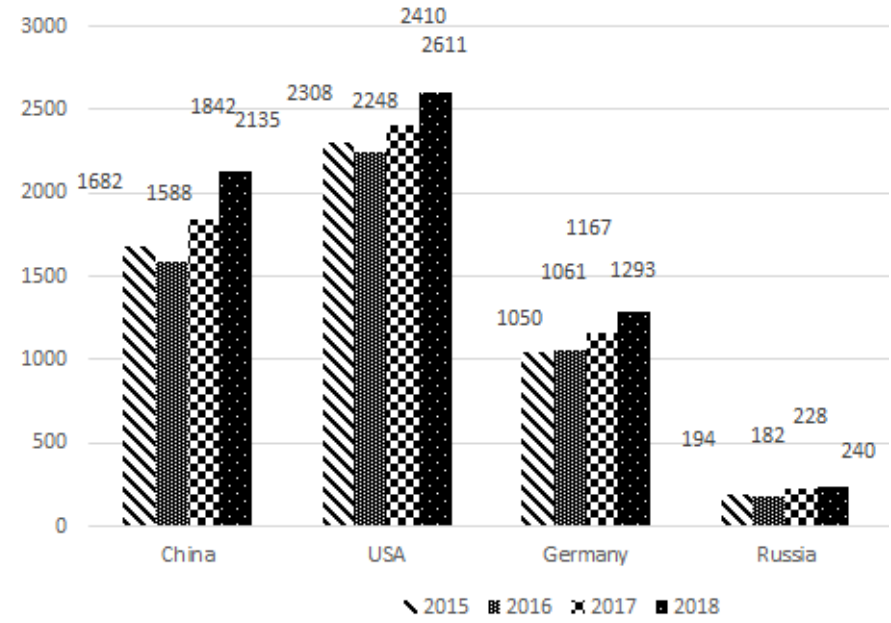

Fig. 4. The import dynamics of countries leading in international trade and Russia for the period of 2015-2018 [8,9]

The development of international trade is significantly influenced by digital technologies that actively penetrate into all business processes and economic activities. At the same time, the digital transformation of international trade touches on different directions, changing the foreign trade specialization of participating countries, speeding up processes of data transmission using cloud technologies, increasing the volume of commercial transactions over the Internet. Now we will consider the main trends in international trade using digital technologies. Table I provides information on the participation of leading countries in the development of online commerce for the period of 2016-2018 [10, 11, 12, 13].

Table 1 data show the dynamics of the growth of online commerce in the leading countries, among which the undisputed leader is China with a volume of $\$ 1330$ billion by the end of 2018, which accounts for $47.6 \%$ of the total ecommerce market in the world. China has made a significant breakthrough in this area thanks to the active adoption of digital technologies and the efficient use of digital trading platforms and online platforms. The second major player in this market is the United States with a volume of online trade of $\$ 513$ billion and a market share of $18.4 \%$. Third place in online trading in 2018 is held by UK with a volume of \$ 199.1 billion and a market share of $7.2 \%$. It should be noted that the
UK has the highest share of online trade in GDP, $7.9 \%$. Germany with a volume of $\$ 105.8$ billion and a market share of $4 \%$ is in the fourth position. Stable and moderate growth in Internet commerce is demonstrated by Japan, South Korea, Canada, Brazil, Russia, India, which are developing rapidly in this direction. Figure 5 provides information on the share of leading countries in the global retail sales through online commerce during 2018.

Data in Figure 5 show that China, the United States, the United Kingdom, Germany and Japan account for 80.3 per cent of the global online retail market, while the share of the remaining countries is small. However, the development of digital technologies and their further penetration into all business processes of international trade allow experts to predict a significant growth of online trade in the future, until 2021 , of approximately $\$ 4.5$ trillion. Digital technologies are also bringing international wholesale to a virtual level through the active use of global electronic networks to transmit and share data in trade transactions. Figure 6 presents the largest wholesale e commerce markets in the world during 2018.

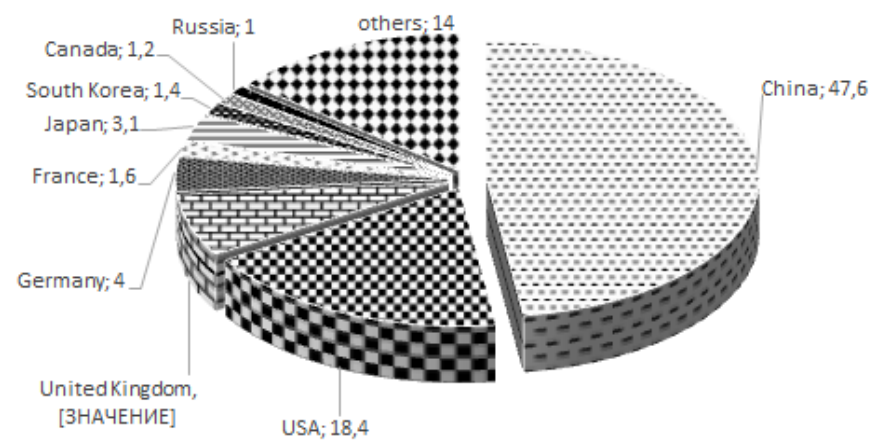

Fig. 5. FThe share of the leading countries' participation in the volume of global retail sales of online trade in $2018[10,11,12,13]$

E-commerce enables companies to conduct cross-border operations more efficiently and flexibly, to interact more closely with global suppliers, and to respond much more quickly to customer demands and expectations [14]. Figure 6 shows that in wholesale online trading, the positions of the leading countries remain virtually unchanged and persist with China, the United States, Japan, Germany, the United Kingdom, which have accumulated significant potential for 
integration and coordination of all participants in the transport, logistics, financial and industrial production systems [18]. Information exchange, tracking of transportation and delivery of goods, remote control and overseeing of logistics operations, planning of the necessary range and quantity of goods for delivery, accounting for financial calculations and deadlines of trade partners' fulfillment of their obligations participants of the Belt and Road project today carry out on the basis of the use of artificial intelligence technologies, Internet of Things, introduction of cloud computing technologies, robotic processes, application of the blockchain system, introduction of cryptocurrencies in settlement operations, widespread use of online platforms and electronic trading platforms. The large-scale development of ecommerce, the intensive development of international trade in information and communication services, the breakthrough development of digital platforms allow the participants of the Belt and Road project to gain not only the benefits of the introduction of digital technologies, but also to take into account all the risks [19]. Considering this, it is sensible to propose the following measures for the development of digitalization processes in the field of international trade, taking into account the need to ensure economic security and control the operations of the Belt and Road project participants (table II)

The implementation of the Belt and Road project provides an opportunity for both developed and developing countries to gain a competitive advantage from the introduction of digital technologies into international trade. The build-up of digital infrastructure will enable them in the future to create a single digital space, ensure data security and privacy, and take a leading position in international trade [20]. The multiplicative effect of the development of digitalization processes in the field of international trade covers all sectors and types of economic activity, providing the formation of new conditions for deepening foreign trade specialization and strengthening the integration interaction of the Belt and Road project participants.

\section{CONCLUSIONS}

The study of the digitalization processes in international trade in terms of the implementation of the Belt and Road Initiative has resulted in the following conclusions:

- The concept of the Belt and Road is aimed at forming integration cooperation between the countries of Eurasia and is a global infrastructure project based on digital technologies in the field of international trade. Digitalization of all business processes will allow the participants of the Belt and Road project to gain a competitive advantage and create a single digital space for the development of international trade at a qualitatively new level.

- Digital transformation of economic relations of the countries participating in the Belt and Road Initiative requires the development of new approaches to the disclosure of the essence and content of the mechanism of interaction of economic actors within the framework of the implementation of the concept of the Belt and trade has a significant impact on the development of related industries and economic activities, which is manifested in the 
TABLE II. ACTIVITIES AIMED TO DEVELOP DIGITALIZATION PROCESSES IN INTERNATIONAL TRADE, TAKING INTO ACCOUNT THE NEED TO ENSURE ECONOMIC SECURITY AND MONITOR THE OPERATIONS OF THE PARTICIPANTS OF THE BELT AND ROAD PROJECT

\begin{tabular}{|c|c|c|}
\hline Event name & Characteristic & Expected results \\
\hline $\begin{array}{l}\text { 1.Creation of digital } \\
\text { infrastructure for the Belt and } \\
\text { Road project }\end{array}$ & $\begin{array}{l}\text { Attracting investment resources for the development of } \\
\text { the telecommunications and energy sector, stimulating } \\
\text { innovations in the field of "smart networks", simplifying } \\
\text { the procedure of creating and operating digital } \\
\text { enterprises. }\end{array}$ & $\begin{array}{l}\text { Creating a new digital infrastructure will simplify supply } \\
\text { chains, boost trade and reduce business costs. Special } \\
\text { institutions will provide security and monitoring of the } \\
\text { operations of the project participants. }\end{array}$ \\
\hline $\begin{array}{l}\text { 2.Development of digitalization } \\
\text { in international trade transport } \\
\text { services }\end{array}$ & $\begin{array}{l}\text { Digitalization of transport based on the use of artificial } \\
\text { intelligence, robotization of handling, formation of } \\
\text { electronic platforms for the provision of wagons, tracking } \\
\text { of cargo transportation, remote control and overseeing } \\
\text { using Internet of Things technologies, electronic vehicle } \\
\text { diagnostics. }\end{array}$ & $\begin{array}{l}\text { Digital transport, as an infrastructure base, will provide a } \\
\text { unified IT environment for interconnected systems, } \\
\text { complexes, traffic control technologies and management of } \\
\text { a unified technological process that brings together all } \\
\text { modes of transportation and participants of the Belt and } \\
\text { Road project. }\end{array}$ \\
\hline $\begin{array}{l}\text { 3.Formation of digital logistics } \\
\text { systems }\end{array}$ & $\begin{array}{l}\text { Introducing artificial intelligence into logistics, applying } \\
\text { the industrial Internet of Things to monitor and account } \\
\text { for logistics and warehouse operations, and using } \\
\text { navigation systems, software, cloud computing } \\
\text { technologies; introduction of the blockchain system into } \\
\text { the supply chain. }\end{array}$ & $\begin{array}{l}\text { Formation of digital logistics systems will enable project } \\
\text { participants to create intelligent communication } \\
\text { mechanisms between participants in international trade, } \\
\text { vehicles, traffic management systems and logistics } \\
\text { infrastructure. The use of the blockchain system in supply } \\
\text { chains will ensure transparency of logistics operations and } \\
\text { eliminate the possibility of theft of cargo. }\end{array}$ \\
\hline $\begin{array}{l}\text { 4.Development of financial } \\
\text { business processes using digital } \\
\text { technologies }\end{array}$ & $\begin{array}{l}\text { Creation and introduction of electronic payment systems, } \\
\text { electronic payments, cryptocurrencies into the system of } \\
\text { international payments of project participants. }\end{array}$ & $\begin{array}{l}\text { Introduction of digital technologies into the financial } \\
\text { transactions of the Belt and Road project participants will } \\
\text { ensure the safety, confidentiality and security of financial } \\
\text { flows. }\end{array}$ \\
\hline $\begin{array}{l}\text { 5.Creation of digital free trade } \\
\text { zones. }\end{array}$ & $\begin{array}{l}\text { Creating favorable conditions for the development of e- } \\
\text { commerce, formation of centers for satellite services and } \\
\text { virtual platforms. }\end{array}$ & $\begin{array}{l}\text { Creation of digital free trade zones will allow to intensify e- } \\
\text { commerce, accelerate commodity exchange and settlement } \\
\text { operations, create conditions for attracting small and } \\
\text { medium-sized businesses to the implementation of the Belt } \\
\text { and Road project. }\end{array}$ \\
\hline $\begin{array}{l}\text { 6.Development of integration } \\
\text { processes in the digitalization of } \\
\text { international trade of participants } \\
\text { of the Belt and Road project }\end{array}$ & $\begin{array}{l}\text { Adapting the regulatory framework, harmonizing the } \\
\text { interests of countries within the framework of political } \\
\text { and economic alliances, stimulating the integration of } \\
\text { participants of the project. }\end{array}$ & $\begin{array}{l}\text { Development of the integration interaction of the } \\
\text { participants of the Belt and Road project will allow to } \\
\text { harmonize economic interests and concentrate efforts on } \\
\text { implementation of the main routes, creation of end-to-end } \\
\text { digital technologies, formation of a single system economic } \\
\text { and information security. }\end{array}$ \\
\hline
\end{tabular}

Road based on the synthesis of institutional theory and systemic approach, which in general constitutes the methodology of this research. We offer to view the role and importance of digital technologies in the development of international trade, deepening foreign trade specialization and enhancing the integration interaction of all participants in the Belt and Road project as a unity of three aspects: infrastructural, economic and multiplicative.

- Analysis of the dynamics of international trade in the digitalization of the world economy during the period of 2015-2018 allowed to justify the leading positions of countries that have accumulated significant potential for the transition to a digital format of interaction, and in the future will dominate the implementation of the Belt and Road project. We have established that today the top five countries (China, USA, Great Britain, Germany and Japan) occupy a significant share of the global retail sales market of online trade in the amount of $80.3 \%$, while the share of other countries is insignificant. A similar situation has developed in the field of wholesale online commerce, where the main participating countries have retained their leading positions. The revealed trends testify to the monopolization of markets by leading players and the growing digital divide in international trade.
- Digital technologies not only have an impact on the development of international trade, but also significantly alter related industries and economic activities. The development of digitalization processes in the field of international trade not only allows the participants of the Belt and Road project to gain advantages from the introduction of digital technologies, but also forms certain problems and risks. In this regard, a set of measures for the development of digitalization processes in the field of international trade has been proposed, taking into account the need to ensure economic security and control the operations of participants in the Belt and Road project. The proposed activities will allow project participants to realize their key competencies through the use of digital technologies in international trade and, as a result, expand international cooperation within the framework of the Belt and Road Initiative.

\section{REFERENCES}

[1] U. Kreickemeier, "International trade and labor markets: Welfare, inequality, and unemployment", World Scientific Publishing Co Pte Ltd. Singapore, 2017, 448 p. 
[11] Overview of the e-commerce market [Electronic resource]. Available at: https://spark.ru/startup/nyigde/blog/39946/obzor-rinka-elektronnojkommertsii.

immigration, international trade, and foreign direct investment", Springer International Publishing, 2017, 288 p.

[3] A. Ehteshami and N. Horesh, "China's presence in the Middle East: The implications of the one belt, one road initiative", Taylor and Francis Ltd. London, United Kingdom, 2017, 220 p.

[4] D. Elder-Vass, "Profit and gift in the digital economy", Cambridge University Press, 2016, 260 p.

[5] V. P. Shuisky, "International trade considering the digitalization of the world economy", Russian foreign economic bulletin, 2019, vol. 7, pp. 720.

[6] A.N. Spartak, "Consequences of digital transformation for the world economy", Russian foreign economic bulletin, 2018, vol. 5. pp. 7-23.

[7] R. W. Jones, "International trade theory and competitive models: Features, values, and criticisms", World Scientific Publishing Co. Pte. Ltd, Singapore, 2017, 388 p.

[8] World Trade Report 2019: The future of services trade [Electronic resource]. Available https://www.wto.org/english/res_e/booksp_e/00_wtr19_e.pdf.

[9] The World Trade Report 2018. The future of world trade: How digital technologies are transforming global commerce [Electronic resource]. Available https://www.wto.org/english/res_e/publications_e/world_trade_report18 -e.pdf.

[10] E-commerce in Russia [Electronic resource]. Available at: https://adindex.ru/specprojects/market-6/commerce/index.phtml.

[12] E-commerce in numbers [Electronic resource]. Available at: https://constanta.co/news/20190108-e-commerce-v-tsifrakh.

[13] Top 10 ecommerce markets of the world. Association of online trade companies [Electronic resource]. Available at: https://www.akit.ru/top10_ecommarket.

[14] G. I. Zekos, "Risk management and corporate governance in 21st century digital economy", Nova Science Publishers, Inc. 2014, 429 p.

[15] A. N. Spartak, "Fourth industrial revolution and international trade", International trade and trade policy, 2018, vol. 2 (14), pp. 5-21.

[16] E. N. Smirnov and S.A. Lukyanov, "Formation and development of the global AI system market", Regional economy, vol. 15, issue 1, pp. 5769.

[17] F. L. Rivera-Batiz and L. A. Rivera-Batiz, "International trade, capital flows and economic development", World Scientific Publishing Co. Singapore, 2018, $464 \mathrm{p}$.

[18] G. Moens, "International trade and business law review", Taylor and Francis, London, 2013, 448 p.

[19] M. Roy and S. Sinha Roy, "International trade and international finance: Explorations of contemporary issues", Springer India, 2016, 595 p.

[20] P. Lo Dickson and C. Allan Cho, "Inside the World's Major East Asian Collections: One Belt, One Road, and Beyond", Elsevier Inc., 2017, 466 p. 